\title{
ANALYSIS OF PAKISTAN-INDIA BILATERAL TRADE: A TRADE INTENSITY APPROACH (EXPORTS AND IMPORTS INTENSITY INDEX)
}

\author{
Dr. Zulfiqar Ali Keeryo
}

Ex. Economic Growth Advisor, Research and Training Wing, Planning and Development Department, Government of Sindh, Karachi, Pakistan

Jazib Mumtaz

PhD Scholar, Department of Social Sciences - Economics, Shaheed Zulfikar Ali Bhutto Institute of Science and Technology, Karachi, Pakistan

\section{Shaman Ali Dayo}

PhD Scholar, Department of Commerce, Shah Abdul Latif University, Khairpur, Pakistan

\begin{abstract}
This paper analyzes the strength and nature of bilateral trading relationship between two countries, Pakistan and India for the period from 2009 to 2018. There are several statistical indices are available to measure trade relation between two nations, but in this paper trade intensity index has been used. The result shows that the Pakistan Exports Intensity Index with respect to India has declined from 0.634 during 2009 to 0.627 during 2018, and it also has never remained stable throughout the period from 2009 to 2018 whereas, the Imports Intensity Index has increased from 1.56 during 2009 to 5.134 in the year 2018. However, it has been observed that both nations have great potential to enhance their bilateral trade, but due to some bottlenecks such as tariff and non-tariff barriers, lack of sea routes, political instability, lack of trust on each other etc., both countries, bilateral trade has affected at large. It is, therefore, recommended that both neighbor countries should increase levels of trust with each other and cooperate each other in matters, so that bilateral trade can be enhanced.
\end{abstract}

Key words: International Trade, Trade Intensity, Exports Intensity, Imports Intensity.

Cite this Article: Zulfiqar Ali Keeryo, Jazib Mumtaz and Shaman Ali Dayo, Analysis of Pakistan-India Bilateral Trade: A Trade Intensity Approach (Exports and Imports Intensity Index), International Journal of Management, 11(12), 2020, pp.1559-1569. http://iaeme.com/Home/issue/IJM?Volume=11\&Issue=12

\section{INTRODUCTION}

After the finishing of the British Raj in 1947, two modern paramount countries to be specific Pakistan and India were shaped, sometime recently cooperation in 1947, they were the same 
nation. At the time of interest, these nations were carved on the premise of ethno-linguistic and devout line, In any case, both Pakistan and India distribute same stock of tenants, common history and proceed to be tormented by indistinguishable issues, and India and Pakistan conciliatory, financial and exchange relations have stay offended, a few of the exceptional issues to complicate the normalization are issues of Kashmir debate, Sharing of water, Crossborder-terrorism, mutilated exchange, Siachen and cross terminating on Line of Control etc.

At the time of freedom 1947, India was the major exchanging accomplice of Pakistan (Zaidi, 2015; Muhammad Salahuddin Ayyubi and Qais Aslam, 2017) but, due to three (03) major wars and diligent respective believe shortage did not permit exchange volumes to develop within the rest of the a long time. There has been a progressive restoration in Pakistan's exchange with India since mid-1990s in common, and after 2004, in specific. Pakistan's total exchange with India expanded more than three times in four a long time from 2004-08 from \$ 612 million to over \$ 2 billion; but at that point remained underneath that esteem till 2012.

Concurring to Hafiz A. Pasha and Muhammad Imran, the exchange between the two countries not affected by financial variables, but there are different other components. At the time of freedom within the year 1947, both economies (Pakistan and India) were intensely forbid, with the share of the Indian showcase in Pakistan's trades at near to one fourth, and (nearly fifty percent of Pakistan's imports arriving from India) over half of Pakistan's imports coming from India. From that point, reciprocal exchange has had a chequered history. Exchange essentially comes to an end after two fought wars in1965 and 1971.

It has been watched within the past, that different arrangements have been given at official levels, but still no right arrangement has showed up towards the bearings. As distant as exchange relations are concerned, it is contended by the famous researchers, specialists, academician, approach producers, organizers etc. on both sides over the a long time that on the off chance that trade ties progress between the two countries, it might lead to individuals to individuals contact and issue of Kashmir would ended up blunted and weakened They cite SinoIndian relationship where India pushed its border debate aside with China and the two concentrated on other viewpoints of connections like financial ties, FDI, two-sided exchange etc. Nowadays, China has developed as the biggest exchanging accomplice of India with exchange having outperformed 65859 million US \$ in 2013-14 from 39747 million US\$ in 1996-97.

In truth, fair after India and Pakistan had ended up majestic states, India's share in Pakistan's worldwide trades and imports accounted for 23.6 per cent and 50.6 per cent separately in 1948-49 which had decreased to 1.3 per cent and 0.06 per cent individually in 1975-76 and after that to simply 0.02 per cent and 0.04 per cent in 2012-13 separately though Pakistan's share in India's worldwide trades and imports was 2.2 per cent and 1.1 per cent individually in 1951-52 which gradually went to decrease to only 0.006 per cent and 0.0006 separately within the year 2012 -13 (Dr. Sandeep Kumar). In this manner, the creator has appeared intrigued in considering reciprocal exchange escalated between the two neighbor nations Islamic Republic of Pakistan and India.

\section{LITERATURE REVIEW}

Muhammad Salahuddin Ayyubi and Qais Aslam (2017) conducted ponder with respect to Pakistan's exchange with India, and attempted to reveal the disaggregated flow Pakistan's exchange with India for a period of 2004-14 at HS-2 digit classification, found that Indian trades to Pakistan delighted in three times more complementarily in Pakistan than Pakistani trades delighted in India, reliably amid the consider period. Pakistan's imports from India were more 
than desires in all the best ten categories in spite of the fact that India had a steady uncovered comparative advantage as it were in three of the beats ten Pakistani imports from India.

Hafiz A. Pasha and Muhammad Imran (2012) Analyzed the two countries exchange volume and its design, gotten to the affect of Most Favored Country (MFN) status to India conjointly highlighted the qualities, shortcomings, openings and dangers, found that both nations have awesome potential to improve the reciprocal exchange, but it may not improve exchange due the presence of tax and non-tariff bsoundaries, so he recommended that both countries ought to take concrete steps, to form inviting environment and apply the arrangement of correspondence and shared participation.

Sundar Raj, P and Ambrose, B (2008) inspected the respective exchange relations between India and Japan by utilized exchange concentrated list procedure for the period from 2001 to 2011, found that both nations have kept up great relations over a period of time, but their reciprocal exchange does not reflect the real potential.

Anurag Anand and Krishma Garg (2016) analyzed the reciprocal exchange relations between Indian and joined together Middle Easterner Emirates (UAE) by utilizing exchange concentrated list for the period from 1991 to 2014, found that both nations have developed as solid financial powers within the final two decades, and have tall scope of exchange participation.

Taneja et al (2015) found that the exchange of trade potential between Pakistan and India is greatest, in case their source from each other, all things, which they source from the rest of the world. Of these the foremost likely things to be exchanged are those in which the provider nation is universally competitive. As it were those things are included in which Uncovered Comparative Advantage (RCA) $>1$.

Kumar, S. (2016) inspected the respective exchange relationship in terms of share in worldwide exchange, reciprocal exchange stream, exchange concentrated, and intra industry exchange for the period from 1996-2014, found that there are numerous bottlenecks in reciprocal between two countries such as tall tax rates and non-tariff boundaries, so prescribed that both nations ought to dispensed with their contrasts and grow their organize through street and ocean course, to upgrade the reciprocal exchange.

Taneja et al. (2013) found that the exchange of trade potential between two countries remains unrealized generally due to impediments in transport and travel offices, prohibitive visa administration, continuation of huge casual exchange streams, and nearness of 'perceived' non-tariff obstructions to exchange between India and Pakistan. As the Remote Coordinate Venture (FDI) administration between the two nations is liberalized, the study recognizes segments which hold potential for ventures, and are likely to extend the exchange linkages between India and Pakistan.

\section{BILATERAL TRADE BETWEEN PAKISTAN AND INDIA}

In improving two-sided exchange, both Pakistan and India have taken different positive steps like in 1996, India agreed Most Favored Country (MFN) status to Pakistan subsequently advertising Pakistan the same exchanging administration because it offers to any other nation within the world. Whereas, Pakistan allowed MFN status to India within the year 2012, and allowed that 1946 things can be imported from India, but on the off chance that we see the patterns in Reciprocal Exchange, it appears that India exchange has remained excess in Pakistan all through the period from the year 2009 to the year 2018 . 
Analysis of Pakistan-India Bilateral Trade: A Trade Intensity Approach (Exports and Imports Intensity Index)

Table 1 Pakistan's Trade with India (US\$ million)

\begin{tabular}{|c|c|c|c|c|c|}
\hline Year & $\begin{array}{c}\text { Export } \\
(\mathbf{X})\end{array}$ & $\begin{array}{c}\text { Imports } \\
(\mathbf{I})\end{array}$ & $\begin{array}{c}\text { Trade } \\
\text { Balance } \\
(\mathbf{X}-\mathbf{I})\end{array}$ & $\begin{array}{c}\text { Total Trade } \\
(\mathbf{X}+\mathbf{I})\end{array}$ & $\begin{array}{c}\text { Trade Balance Ration } \\
(\mathbf{X}-\mathbf{M} / \mathbf{X}+\mathbf{M}) * \mathbf{1 0 0}\end{array}$ \\
\hline 2018 & 383.046 & 1928.465 & -1545.42 & 2311.511 & -66.858 \\
\hline 2017 & 334.752 & 1696.136 & -1361.38 & 2030.888 & -67.034 \\
\hline 2016 & 348.102 & 1644.388 & -1296.29 & 1992.490 & -65.059 \\
\hline 2015 & 312.284 & 1669.286 & -1357.00 & 1981.570 & -68.481 \\
\hline 2014 & 392.214 & 2104.804 & -1712.59 & 2497.018 & -68.585 \\
\hline 2013 & 402.747 & 1874.062 & -1471.32 & 2276.809 & -64.622 \\
\hline 2012 & 347.994 & 1572.585 & -1224.59 & 1920.579 & -63.762 \\
\hline 2011 & 272.864 & 1607.346 & -1334.48 & 1880.210 & -70.975 \\
\hline 2010 & 274.983 & 1559.921 & -1284.94 & 1834.904 & -70.028 \\
\hline 2009 & 235.323 & 1080.404 & -845.081 & 1315.727 & -64.229 \\
\hline
\end{tabular}

Source: ITC

The trade situation with India has been deplorable state and remain deficit from 2009 to 2018. The above table shows that during the year 2009 Pakistani exports to India remained US\$ 235.323 million as compared to imports US\$ 1080.404 million from India. It tells negative trade balance which stands at US\$ - 845.081 million. The total trade during the concerned year stood US\$ 1315.727 million, which showed a negative ratio $-64.229 \%$. While in 2010 , the export increased and reached to US\$274.983 million as compared to much increased imports that stood US\$ 1559.921 million, which also showed a negative trade balance that remained US\$ 1284.94 million and total trade with India stood US\$ 1834.904 which negative ratio stood 70.028 .

During the year 2011 Pakistan export to India stood US\$ 272.864 million) as compare to import which remained US\$ 1607.346 million, which also tells negative trade balance stood US\$ -1334.48 million the total trade balance with India reached in the same year was US\$ 1880.210 million whose ratio remained negative $-70.975 \%$.

In year 2012, Pakistan export to India reached to US\$ 347.994 million and total imports from India stood US\$ 1572.585 million, which again brought negative trade balance which stood US\$ - 1224.59 million. Total trade with India remained US\$ 1920.579 million with a negative ratio that stood $-63.762 \%$. While in 2013, total Pakistan exports to India remained US\$ 402.747 million against the imports US\$ 1874.062 million from India, which brought negative trade balance with India which stood US\$ -1471.32 million. Total trade between Pakistan and India stood US\$2276.809 million and again, there is negative ration which stood negative $64.622 \%$.

In year 2014 the export reached to US\$ 392.214 million against the imports US\$ 2104.804 million again trade balance become negative, which stood US\$ -1712.59 million the total trade remained with India was US\$2497.018 million with negative ration-68. 585\%. During the year 2015, the above table shows that the export decrease and reached to US\$ 312.284 million against imports, which stood to US\$ 1669.286 million with negative trade balance US\$ 1357.00 million during the same year total trade reached to US\$1981.570 million with negative 
ratio $-68.481 \%$. While In year of 2016 total export slightly increase and stood with US\$ 348.102 million against the imports US\$ 1644.388 million again with a negative trade balance of US\$ 1296.29 million as far as total trade with India is concerned that is US\$ 1992.490 million with negative ratio $-65.059 \%$.

Total export during the year of 2017 with remaining \$334.752 (M) against the imports US\$ 1696.136 million, which again brought negative trade balance US\$ -1361.38 million. Total trade between Pakistan and India in during same year remained US\$ 2030.888 million, which brought negative ratio $-67.034 \%$. While in year 2018, total export to India stood with US\$ 383.046 million against the import US\$ 1928.465 million, which brought again negative trade balance with US\$ -1545.42 million, total trade between Pakistan and India stood US\$ 2311.511 million with negative ratio $-66.858 \%$.

Table 2 Role of Pakistan and India in Each Other's Exports and Imports

\begin{tabular}{|c|c|c|c|c|}
\hline Year & $\begin{array}{c}\text { Percentage share of } \\
\text { Pakistan in India's } \\
\text { exports }\end{array}$ & $\begin{array}{c}\text { Percentage share of } \\
\text { Pakistan in India's } \\
\text { imports }\end{array}$ & $\begin{array}{c}\text { Percentage share of } \\
\text { India in Pakistan's } \\
\text { exports }\end{array}$ & $\begin{array}{c}\text { Percentage share of } \\
\text { India in Pakistan's } \\
\text { imports }\end{array}$ \\
\hline 2018 & 1.62 & 3.20 & 0.73 & 0.10 \\
\hline 2017 & 1.53 & 2.95 & 0.61 & 0.11 \\
\hline 2016 & 1.70 & 3.50 & 0.61 & 0.13 \\
\hline 2015 & 1.41 & 3.79 & 0.74 & 0.12 \\
\hline 2014 & 1.59 & 4.43 & 0.68 & 0.12 \\
\hline 2013 & 1.60 & 4.28 & 0.65 & 0.08 \\
\hline 2012 & 1.41 & 3.08 & 0.54 & 0.10 \\
\hline 2011 & 1.08 & 3.69 & 0.56 & 0.08 \\
\hline 2010 & 1.28 & 4.16 & 1.01 & 0.09 \\
\hline 2009 & 1.34 & 3.42 & 0.82 & 0.10 \\
\hline
\end{tabular}

Source: WITS

The above table During year 2018, shows total Percentage share of Pakistan in India's exports which stood $1.62 \%$ and Percentage share of Pakistan in India's imports which stood $3.20 \%$ as compare to Percentage share of India in Pakistan's exports which stood $0.73 \%$ while Percentage share of India in Pakistan's imports which stood $0.10 \%$ which again brought negative trade ratio with India. While during year of 2017, the Percentage share of Pakistan in India's exports which stood $1.53 \%$ and Percentage share of Pakistan in India's imports which stood $2.95 \%$ as compare to Percentage share of India in Pakistan's exports which stood $0.61 \%$ while Percentage share of India in Pakistan's imports which stood $0.11 \%$ which again brought negative trade ratio with India.

The above table during year 2016, shows total Percentage share of Pakistan in India's exports which stood $1.70 \%$ and Percentage share of Pakistan in India's imports which stood $3.50 \%$ as compare to Percentage share of India in Pakistan's exports which stood $0.61 \%$ while Percentage share of India in Pakistan's imports which stood $0.13 \%$ which again brought negative trade ratio with India. While During year 2015, the Percentage share of Pakistan in India's exports which stood $1.41 \%$ and Percentage share of Pakistan in India's imports which stood $3.79 \%$ as compare to Percentage share of India in Pakistan's exports which stood $0.74 \%$ 
while Percentage share of India in Pakistan's imports which stood $0.12 \%$ which again brought negative trade ratio with India.

In year 2014, Percentage share of Pakistan in India's exports which stood $1.60 \%$ and Percentage share of Pakistan in India's imports which stood $1.59 \%$ as compare to Percentage share of India in Pakistan's exports which stood $4.43 \%$ while Percentage share of India in Pakistan's imports which stood $0.12 \%$ which again brought negative trade ratio with India.

The above table shows during the year 2013, Percentage share of Pakistan in India's exports, which stood $1.60 \%$ and Percentage share of Pakistan in India's imports, which stood $4.28 \%$ as compared to Percentage share of India in Pakistan's exports which stood $0.65 \%$ while Percentage share of India in Pakistan's imports which stood0. $08 \%$, which again brought negative trade ratio with India. While year 2012, total Percentage share of Pakistan in India's exports which stood $1.41 \%$ and Percentage share of Pakistan in India's imports which stood 3.08 as compare to Percentage share of India in Pakistan's exports which stood $0.54 \%$ while Percentage share of India in Pakistan's imports which stood $0.10 \%$ Which again brought negative trade ratio with India.

During the year 2011, Percentage share of Pakistan in India's exports stood 1.08 and Percentage share of Pakistan in India's imports, which stood 3.69\% as compared to Percentage share of India in Pakistan's exports which stood $0.56 \%$ while Percentage share of India in Pakistan's imports which stood 0.08 .

According to above table which shows that during the year 2010, Percentage share of Pakistan in India's exports stood $1.28 \%$ and Percentage share of Pakistan in India's imports which stood $4.16 \%$ as compare to Percentage share of India in Pakistan's exports which stood $1.01 \%$ while Percentage share of India in Pakistan's imports which stood $0.09 \%$ which again brought negative trade ratio with India. While year 2009, total Percentage share of Pakistan in India's exports which stood $1.34 \%$ and Percentage share of Pakistan in India's imports which stood 3.42 as compare to Percentage share of India in Pakistan's exports which stood $0.82 \%$ while Percentage share of India in Pakistan's imports which stood $0.10 \%$ Which again brought negative trade ratio with India.

\section{GLOBAL TRADE PROFILE OF PAKISTAN AND INDIA}

Table 3 Share of Pakistan and India in World Trade from 2009-2018

\begin{tabular}{|c|c|c|c|c|c|c|}
\hline Year & \multicolumn{3}{|c|}{ Pakistan } & \multicolumn{3}{c|}{ India } \\
\hline & Exports & Imports & Total Trade & Exports & Imports & Total Trade \\
\hline 2018 & 0.122 & 0.305 & 0.214 & 1.669 & 2.577 & 2.127 \\
\hline 2017 & 0.124 & 0.322 & 0.224 & 1.686 & 2.496 & 2.094 \\
\hline 2016 & 0.129 & 0.293 & 0.211 & 1.639 & 2.224 & 1.933 \\
\hline 2015 & 0.134 & 0.265 & 0.200 & 1.609 & 2.361 & 1.987 \\
\hline 2014 & 0.131 & 0.251 & 0.191 & 1.683 & 2.433 & 2.058 \\
\hline 2013 & 0.133 & 0.231 & 0.182 & 1.783 & 2.469 & 2.126 \\
\hline 2012 & 0.133 & 0.236 & 0.185 & 1.574 & 2.644 & 2.110 \\
\hline 2011 & 0.140 & 0.238 & 0.189 & 1.667 & 2.525 & 2.098 \\
\hline 2010 & 0.141 & 0.245 & 0.193 & 1.460 & 2.284 & 1.875 \\
\hline 2009 & 0.142 & 0.250 & 0.196 & 1.431 & 2.109 & 1.774 \\
\hline
\end{tabular}

Source: ITC 
The above table shows during year 2018, Percentage share of Pakistan export to India stands with which stood $.122 \%$ while Percentage share of Pakistan import from India which remain $0.305 \%$ and total Pakistan trade ratio stand with 0.214 as compare to Percentage share of Indian exports to Pakistan which remains $1.669 \%$ while Percentage share of Indian imports from Pakistan stands $2.577 \%$ and total trade ratio of Indian remain with Pakistan is 2.127 which again brought positive trade ratio for India. While year 2017, Percentage share of Pakistan export to India stands with which stood .124\% while Percentage share of Pakistan import from India which remain $0.322 \%$ and total Pakistan trade ratio stand with $0.224 \%$ as compare to Percentage share of Indian exports to Pakistan which remains $1.686 \%$ while Percentage share of Indian imports from Pakistan stands $2.496 \%$ and total trade ratio of Indian remain with Pakistan is 2.094 which again brought positive trade ratio for India.

During the year 2016, the above table shows that Percentage share of Pakistan export to India stands with which stood $0.129 \%$ while Percentage share of Pakistan import from India which remain $0.293 \%$ and total Pakistan trade ratio with India stands with $0.211 \%$ as compare to Percentage share of Indian exports to Pakistan which remains $1.639 \%$ while Percentage share of Indian imports from Pakistan stands with $2.224 \%$ and total trade ratio of Indian remain with Pakistan is $1.933 \%$ which again brought positive trade ratio for India. While year 2015, Percentage share of Pakistan export to India stands with which stood $.134 \%$ while Percentage share of Pakistan import from India which remain $0.265 \%$ and total Pakistan trade ratio stand with $0.200 \%$ as compare to Percentage share of Indian exports to Pakistan which remains $1.609 \%$ while Percentage share of Indian imports from Pakistan stands $2.361 \%$ and total trade ratio of Indian remain with Pakistan is $1.987 \%$ which again brought positive trade ratio for India

The above table shows during year 2014, Percentage share of Pakistan export to India stands with which stood $0.131 \%$ while Percentage share of Pakistan import from India which remain $0.251 \%$ and total Pakistan trade ratio stand with 0.191 as compare to Percentage share of Indian exports to Pakistan which remains $1.683 \%$ while Percentage share of Indian imports from Pakistan stands $2.433 \%$ and total trade ratio of Indian remain with Pakistan is 2.058 which again brought positive trade ratio for India. While year 2013, Percentage share of Pakistan export to India stands with which stood .133\% while Percentage share of Pakistan import from India which remain $0.321 \%$ and total Pakistan trade ratio stand with $0.181 \%$ as compare to Percentage share of Indian exports to Pakistan which remains $1.783 \%$ while Percentage share of Indian imports from Pakistan stands $2.469 \%$ and total trade ratio of Indian remain with Pakistan is 2.126 which again brought positive trade ratio for India.

The above table shows during year 2012, Percentage share of Pakistan export to India stands with which stood $0.133 \%$ while Percentage share of Pakistan import from India which remain $0.236 \%$ and total Pakistan trade ratio with India stand with 0.185 as compare to Percentage share of Indian exports to Pakistan which remains $1.574 \%$ while Percentage share of Indian imports from Pakistan stands $2.644 \%$ and total trade ratio of Indian remain with Pakistan is 2.110 which again brought positive trade ratio for India. While year 2011, Percentage share of Pakistan export to India stands with which stood $0.140 \%$ while Percentage share of Pakistan import from India which remain $0.238 \%$ and total Pakistan trade ratio stand with $0.189 \%$ as compare to Percentage share of Indian exports to Pakistan which remains $1.667 \%$ while Percentage share of Indian imports from Pakistan stands $2.525 \%$ and total trade ratio of Indian remain with Pakistan is 2.098 which again brought positive trade ratio for India.

The above table shows during year 2010, Percentage share of Pakistan export to India stands with which stood $0.141 \%$ while Percentage share of Pakistan import from India which remain $0.245 \%$ and total Pakistan trade ratio with India stand with 0.193 as compare to Percentage share of Indian exports to Pakistan which remains $1.460 \%$ while Percentage share 
of Indian imports from Pakistan stands $2.284 \%$ and total trade ratio of Indian remain with Pakistan is 1.875 which again brought positive trade ratio for India. While year 2009, Percentage share of Pakistan export to India stands with which stood $0.141 \%$ while Percentage share of Pakistan import from India which remain $0.250 \%$ and total Pakistan trade ratio stand with $0.196 \%$ as compare to Percentage share of Indian exports to Pakistan which remains $1.431 \%$ while Percentage share of Indian imports from Pakistan stands $2.109 \%$ and total trade ratio of Indian remain with Pakistan is 1.774 which again brought positive trade ratio for India.

\section{METHODOLOGY}

This study analyzed the exchange connection between Islamic Republic of Pakistan and India. The information of two-sided exchange between them has been collected from UNCOMTRADE Insights Database for the period from 2009 to 2018, and exchange concentrated Record strategy which was created by K. Kojima (1964) has been utilized. In any case, numerous strategies are accessible to ponder exchange relations, but due to constrained purposes send out escalated list and consequence escalated list have been utilized. This exchange escalated is being utilized to the degree the share of one country's exchange with another nation as an extension of the latter's share of world exchange. This method has been too utilized by different analysts such as Sundar Raj, P and Ambrose, B., Anurag Anand and Krishhma Garg, etc.

\section{ANALYSIS OF TRADE INTENSITY INDEX}

The exchange escalated list can be thought as a uniform trade share. In other words, the measurement tells us whether or not a locale sends out more (as a rate) to a given goal than the world does on normal. It is deciphered in much the same way as a trade share. It does not endure from any "size" inclination, so ready to compare the measurement over locales, and overtime when trades are developing quickly. The exchange concentrated measurement is the proportion of two trade offers. The numerator is the share of the goal of intrigue within the trades of the locale beneath consider. The denominator is the share of the goal of intrigue within the trades of the world as an entire.

Extend of values: The esteem of Exchange Escalated Record ranges from 0 to 1 . In the event that the esteem is 0 , it infers no exchange relationship between accomplice nations. On the other hand, in the event that the esteem is 1 shows tall exchange relations. In case moment escalated list is more (or less) than 1, it demonstrates that nation, Pakistan is bringing in more (or less) from nation India than could be anticipated from that country's share in add up to world exchange. In send out as well, on the off chance that the esteem is it suggests an trade interface between these two nations is irrelevant and on the off chance that the esteem is closer to 1 that shows that execution is noteworthy and in the event that it surpasses 1 it shows that Pakistan is trading more to nation India than could be anticipated from that country's share in world exchange.

In this examination, in the event that the force between two nations are well underneath 1 , the creator accepts that the two nations have much exchange potential to harvest between them. Reciprocal exchange connections between Pakistan and India, which is depicted in terms of consequence and send out escalated lists, makes a difference to recognize how plan the nations are exchanging with each other. The exchange concentrated record assist has been plunged into two parts such as sending out escalated record and imports escalated record. These records are characterized as under: 
The Export intensity index between Pakistan with respect to India (XIlijt) is shown as under:

\section{Export Intensity Index (XIIipt)}

XIIipt $=[$ Xip / Xi] $/[\mathrm{Mp} /(\mathrm{Mw}-\mathrm{Mi})]$

Where:

XIIipt $=$ Export intensity index of trade of Pakistan with India:

Xip= Exports of Pakistan to India

$\mathrm{X} \mathbf{i}=$ Total Exports of Pakistan

$\mathrm{Mp}=$ Total Imports of India

$\mathrm{Mw}=$ Total World Imports

$\mathrm{Mi}=$ Total Imports of Pakistan

$\mathrm{t}=2003$ to 2018

Import intensity index (MIIipt) can also be measured in the similar way

MIIipt $=[\mathrm{Mip} / \mathrm{Mi}] /[\mathrm{Xj} /(\mathrm{Xw}-\mathrm{Xi})]$

Where:

\section{MIIipt $=$ Import intensity index of trade of Pakistan with India}

Mip= Imports of Pakistan from India

$\mathrm{Mi}=$ Total Imports of Pakistan

$\mathrm{Xw}=$ Total World Exports

$\mathrm{Xi}=$ Total Exports of Pakistan

$\mathrm{t}=2003$ to 2018

Table 4 Trade Intensity between India and Pakistan 2009-2018

\begin{tabular}{|c|c|c|}
\hline Year & Export Intensity Index & Import Intensity Index \\
\hline 2018 & 0.627 & 5.134 \\
\hline 2017 & 0.612 & 5.692 \\
\hline 2016 & 0.761 & 8.464 \\
\hline 2015 & 0.596 & 8.753 \\
\hline 2014 & 0.651 & 7.390 \\
\hline 2013 & 0.648 & 6.748 \\
\hline 2012 & 0.533 & 6.750 \\
\hline 2011 & 0.426 & 6.771 \\
\hline 2010 & 0.561 & 1.250 \\
\hline 2009 & 0.634 & 1.569 \\
\hline
\end{tabular}

Source: ITC

The above table 4 depicts the Islamic Republic of Pakistan's Export Intensity Index and Import Intensity Index with India. It is clear from the above table that the Pakistan Exports Intensity Index with respect to India has declined from 0.634 during 2009 to 0.627 during 2018, and it also has never remained stable throughout the period from 2009 to 2018 therefore, one can say for this declining trend that the Pakistan could not diversified its exports basket over the years to India market due to many bottlenecks. According to Hafiz A. Pasha and Muhammad Imran (2012), Pakistan and India trade influenced not only for economic factors, 
but there are various factors such as tariff and non-tariff factors, lack of road and sea routes etc. Pakistan's exports have stuck to some traditional items such as fresh, dried dates, cement etc., (Dawn Newspaper, 2019) whereas, the Imports Intensity Index is more than one. This indicates Pakistan imports more than exports. In 2009, the Imports Intensity Index was 1.56 and reached at 5.134 in the year 2018. However, I had also fluctuated due these bottlenecks. But through, the trade intensity has remained in favor of India.

\section{CONCLUSION}

It has been concluded from the study that the significance of the respective exchange in both nations economy's shows, but India has more significance in Pakistan's economy with regard to in general exchange, while, Pakistan economy has small significance in India economy amid the think about the period from 2009 to 2018. Pakistan Trades Escalated Record with regard to India has declined from 0.634 amid 2009 to 0.627 amid 2018, and it too has never remained steady all through the period, though, the Imports Escalated File has expanded from 1.569 to 5.134 amid the final ten a long time. Concurring to the State Bank of Pakistan, Pakistan and India are two most crowded country and biggest economies of the South Asian Locale. In any case, there official reciprocal exchange remains unimportant and not one or the other nation falls within the category of beat ten exchanging accomplices of each other somewhat due to their history of being moderately closed economies. India's outside exchange, openness remained low at 31 percent than 38 percent for percent in Pakistan and the average for South Asia (65 percent) and ASEAN countries (144 percent) in 2003.

At present, both nations' relations are not well. In this manner, it is prescribed that the both neighbor nations ought to create an inviting environment and to form inviting approaches and participate with each other. In any case, both will influence, but India will influence more than Pakistan. Concurring to Pakistan Tea Affiliation (PTA), Pakistan imports tea in tremendous amount each year on the off chance that it forces to force the overwhelming consequent obligation on this single great of India, at that point they will know which nation influence more in respective exchange. It cited that the share of Indian tea in add up to imports had risen to $8.45 \%$ in 2018 out of add up to the moment of 189,809 tons. The share of Indian in 2016 and 2017 was $6.77 \%$ against adding up to imports of 172,910 tons and 173,994 tons individually.

\section{REFERENCE}

[1] Anurag Anand and Krishma Garg. (2016). A Study of India's Trade Intensity with United Arab Emirates: An Overview. International Journal of Electrical, Electronics and Computers (EEC Journal), 22-18.

[2] Hafiz A. Pasha and Muhammad Imran. (2012). The Prospects for Indo-Pakistan Trade. The Lahore Journal of Economics, 293-313.

[3] Kumar, S. (2016). BILATERAL TRADE RELATIONS BETWEEN INDIA AND PAKISTAN: RECENT EXPERIENCE AND FUTURE PROSPECTS. Indian Journal of Economics and Development, 535.

[4] Muhammad Salahuddin Ayyubi and Qais Aslam. (2017). Pakistan's Trade with India Disaggregated Prospects. Forman Journal of Economic Studies, 33-54.

[5] Nisha Taneja, M. M. (2013). Normalizing India Pakistan Trade. New Delhi: INDIAN COUNCIL FOR RESEARCH ON INTERNATIONAL ECONOMIC RELATIONS. 
[6] Nisha Taneja, S. B. (n.d.). Recent Trends in India-Pakistan Trade (2015-16). New Delhi : India Council for Research on International Economic Relations (ICRIER).

[7] Sundar Raj, P. and Ambrose, B. (2008). A BRIEF ANALYSIS OF INDIA-JAPAN BILATERAL TRADE: A TRADE INTENSITY APPROACH. International Journal of Commerce and Management, 42.

[8] Shahid, J. (2019, April). Date exports fall after Indian duties. Retrieved from www.dawn.com: https://www.dawn.com/news/1478246

[9] ITC. (2018). Bilateral trade between Pakistan and India. Retrieved from,www.trademap.org:https://www.trademap.org/Bilateral_TS.aspx?nvpm=1\%7c586\% $7 \mathrm{c} \%$ 7c699\%7c\%7cTOTAL\%7c\%7c\%7c2\%7c1\%7c1\%7c2\%7c2\%7c1\%7c1\%7c1\%7c1\%7c1

[10] WITS. (2018). Pakistan Product Export Product Share to World. Retrieved from wits.worldbank.org:https://wits.worldbank.org/CountryProfile/en/Country/PAK/StartYear/200 9/EndYear/2018/TradeFlow/Export/Indicator/XPRT-PRDCT-

SHR/Partner/WLD/Product/Total 